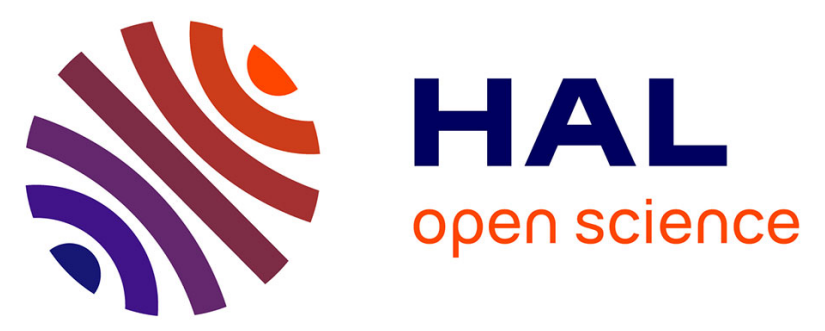

\title{
Improving the durability of asphalt mixtures with hydrated lime: Field results from recent French sections
}

Didier Lesueur, Pierre Metais, Patrick Pibis, Samyr El Bedoui, Hervé Ruat, Stéphane Bouron, Ferhat Hammoum

\section{- To cite this version:}

Didier Lesueur, Pierre Metais, Patrick Pibis, Samyr El Bedoui, Hervé Ruat, et al.. Improving the durability of asphalt mixtures with hydrated lime: Field results from recent French sections. RILEM International Symposium on Bituminous Materials, ISBM Lyon 2020, Dec 2020, LYON, France. 6 p. hal-03165056

\section{HAL Id: hal-03165056 https://hal.science/hal-03165056}

Submitted on 10 Mar 2021

HAL is a multi-disciplinary open access archive for the deposit and dissemination of scientific research documents, whether they are published or not. The documents may come from teaching and research institutions in France or abroad, or from public or private research centers.
L'archive ouverte pluridisciplinaire HAL, est destinée au dépôt et à la diffusion de documents scientifiques de niveau recherche, publiés ou non, émanant des établissements d'enseignement et de recherche français ou étrangers, des laboratoires publics ou privés. 


\title{
Improving the durability of asphalt mixtures with hydrated lime: Field results from recent French sections
}

\author{
Didier Lesueur ${ }^{1}$, Pierre Métais ${ }^{1}$, Patrick Pibis ${ }^{2}$, Samyr El Bedoui ${ }^{3}$, Hervé Ruat ${ }^{4}$, Sté- \\ phane Bouron ${ }^{5}$ and Ferhat Hammoum ${ }^{5}$ \\ ${ }^{1}$ Lhoist, Paris, France / ${ }^{2}$ CD88, Golbey, France / ${ }^{3}$ DIR NO, Rouen, France \\ $/{ }^{2}$ Cerema, Nancy, France $/{ }^{2}$ IFSTTAR, Nantes, France \\ didier.lesueurlhoist.com
}

\begin{abstract}
Although known for a long time, hydrated lime (HL) still attracts a strong technical interest as an asphalt additive.

This presentation describes recent field results obtained in France in two different contexts:

- First, we describe the 7-yrs experience obtained on 20 sections with and without HL in the mountainous Vosges department. This eastern part of France is characterized by cold winters and significant elevation, making it a pretty challenging environment for asphalt mixtures. The types of mixtures were essentially semidense Asphalt Concrete (French BBSG). The results after 7-yrs of monitoring are described.

- Second, we describe the 5-yrs experience obtained on 5 sections with and without HL in the oceanic climate of Highway A84 in Normandy. The types of mixtures were also semi-dense Asphalt Concrete (French BBSG) and a thorough testing program was established from the beginning. The results after 5-yrs of monitoring are described.

As a result, the results allow quantifying the impact of $\mathrm{HL}$ in terms of durability improvement.
\end{abstract}

Keywords: Hydrated Lime, Asphalt Mixture, Durability

\section{Introduction}

The use of hydrated lime in asphalt surfacings is a tried and tested practice which developed on a large scale in the late 1970s in the United States, as a response to the widespread and premature appearance of damage such as raveling and aggregate stripping [1]. In Europe the practice is growing, and the Netherlands has the greatest experience, since in this country, Porous Asphalt (PA), the main asphalt type for local motorways, always contains $2 \%$ of hydrated lime [1]. Recently, Switzerland and Austria have also been using this additive on a large scale for all types of surfacings [5].

In France, interest was renewed in 2004 due to the generalization of the use of hydrated lime in surface courses by private highway company Société des Autoroutes du Nord Est de la France (SANEF) [1]. This decision followed the observation that the 
first PA laid on its network with hydrated lime in it in 1984, then a first in France, had an exceptional lifetime of over 16 years [2].

In a similar way, many project owners in various countries across the world now associate the presence of hydrated lime in asphalt mixtures with extended durability of the order of $25 \%$, or greater [1]. This effect is due to the multifunctional effect of hydrated lime in asphalt mixtures, which materializes in an improved resistance to moisture damage, a reduced age-hardening and improved mechanical properties [3].

\section{Vosges department sections}

The winters of recent years have caused extensive damage to French road surfaces, in particular with the premature appearance of raveling and aggregate stripping. Damage is generally accentuated by repeated freeze-thaw cycles in the presence of water and de-icing salts. This degradation is aggravated by the phenomenon of expansion of water which, when it freezes, can lead to the delamination of the surface layers [4].

In the recent years, the Vosges Département Road Agency has observed a reduction in the service lives of surface courses, mainly Semi-Coarse Asphaltic Concretes (BBSG - AC surf according to NF EN 13108-1), with disorders such as raveling and aggregate stripping, associated with deficient resistance to moisture damage. They thus decided to put hydrated lime to the test.

\subsection{Materials}

A preliminary study was performed observing that the shorter service lives observed with BBSGs were not associated with a decrease in performance as measured in the Duriez test (NF EN 12697-12 method B) where the loss of compressive strength after total immersion ( 7 days in water at $18^{\circ} \mathrm{C}$ ) is recorded. It was therefore proposed to make the test more severe by extending it to 14 days, increasing the temperature to $40^{\circ} \mathrm{C}$ and adding $2 \% \mathrm{NaCl}$ in the water. With this new set-up, the retained resistance of a reference BBSG dropped from $86 \%$ (standard) down to $52 \%$ [5,6]. Current specifications being $>80 \%$, the mixture was classified as having sufficient resistance with standard procedure but this was not true anymore with the severe one.

In parallel, mixtures with hydrated lime had more than $90 \%$ retained resistance for all testing conditions [5,6]. Thus, it was decided to construct 20 test sections in 201113 at elevations 300-1090 m, with traffic intensities 35-500 heavy vehicles/day [6]. Sections consisted in BBSG mixtures with 5.7-5.8\% binder (50/70 pen grade bitumen except for 2 sections in $35 / 50$ and 70/100) with or without up to $1.8 \%$ hydrated lime [10]. All mixtures were produced in an industrial batch plant, based on two local aggregate sources (granite and crushed Meuse river gravel).

\subsection{Monitoring Methodology}

For each section, the Mean Texture Depth (MTD - NF EN 13036-1) was measured by the Vosges Department laboratory over time every 20 meters with "axis" (center line) 
and "wheel-path" values. 20 points were measured for each lane and the average value was reported.

\subsection{Results}

Average MTD for each section was measured as a function of age with and without lime (Fig. 1). For all new BBSGs, the MTD after construction was equal on average to $0.59 \mathrm{~mm}$. The standard deviation for the 20 values for all the sections was $0.04 \mathrm{~mm}$, showing great uniformity. No significant difference on construction appeared between the formulae with and without lime (Fig. 1).

The differences started to appear from the $3^{\text {rd }}$ year on (Fig. 1). At this age, the average MTD of the mixtures without lime reached $0.68 \mathrm{~mm}$, whereas that of surfacings with lime stayed close to $0.61 \mathrm{~mm}$. At the same time the standard deviation of the nonmodified surfacings doubled compared to its initial value, indicating a greater heterogeneity of the surface conditions. The field observations enabled this increase to be associated with initial, and scattered, raveling/stripping. The increased standard deviation $(0.07 \mathrm{~mm})$ thus illustrated that surface damage was starting to develop.

After the $4^{\text {th }}$ year, these differences became even more accentuated (Fig. 1) with an average MTD of $0.79 \mathrm{~mm}$ for BBSGs without lime, compared to $0.66 \mathrm{~mm}$ for the treated-ones. These differences remained similar at the end of the $5^{\text {th }}$ year (Fig. 1), with a number of sections without lime exceeding $0.8 \mathrm{~mm}$. Degradations was now so marked that some sections required preventive maintenance (microsurfacing or surface dressing). The scatter in MTD was also highly pronounced without lime, with a standard deviation reaching $0.12 \mathrm{~mm}$, well above the repeatability of the method (12\%), showing that the degradations were heterogeneously distributed.

After 6 years the sections with lime still had a satisfactory average value of $0.69 \mathrm{~mm}$ and a standard deviation of $0.09 \mathrm{~mm}$, i.e. the value observed for BBSGs without lime after 3 years.

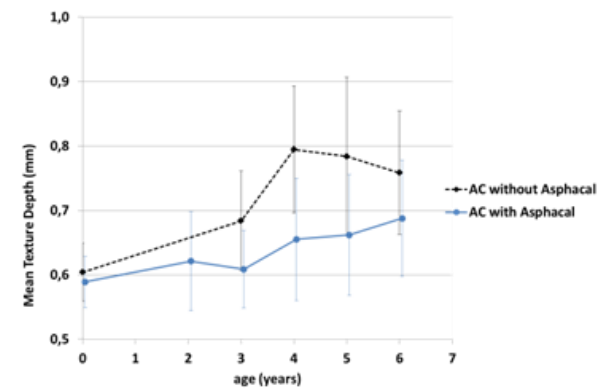

Fig. 1. Mean Texture Depth as a function of pavement age for the 20 sections built in 2011-13 based on BBSG with or without Asphacal ${ }^{\circledast}$ hydrated lime in the Vosges Département. 


\section{$3 \quad$ Highway A84 sections}

\subsection{Materials}

$37000 \mathrm{t}$ of AC surf 0/14 (BBSG) were laid in 7-cm-thick layers on highway A84 between the cities of Caen (Normandy) and Rennes (Brittany) in 2012-13. The mixtures were made with siliceous sandstone and 4.4\% 35/50 bitumen. 15\% Reclaimed Asphalt Pavement (RAP) was introduced in all productions amounting to $0.7 \%$ additional binder in the mixture. Hydrated lime was added at $0,0.5$ or $1.5 \%$. All mixtures were produced in an industrial batch plant. The sections were 1.6 to $6 \mathrm{~km}$-long and where built on both directions of the highway.

\subsection{Monitoring Methodology}

Monitoring was organized since the beginning of the construction works by Cerema Rouen and Ifsttar Nantes. Raw materials and mixtures were tested at the initial stage. Slabs were extracted after 3 and 5 years. They were cut to various dimensions with widths $400-600 \mathrm{~mm}$ and lengths $600-700 \mathrm{~mm}$. Specimens from the wearing course could be extracted by further sawing and/or coring.

The 35/50 bitumen was tested as such and after short-term (Rolling Thin Film Oven Test RTFOT EN 12607-1) and long term (Pressure Aging Vessel PAV EN 14769) aging. Binders were also recovered (EN 12697-3) from the all mixtures. All binders were tested for standard properties (penetration EN 1426, Ring \& ball softening temperature EN1427) and advanced rheological ones (complex shear modulus EN 14770 and Bending Beam Rheometer BBR EN 14771). In parallel, chemical indicators were also measured on the binders such as the asphaltenes content (based on a test method similar to ASTM D6560) and FTIR indices [7].

The mixtures were tested for moisture damage using a test adapted from EN 1269712, performed on the specimens cored from the slabs, then broken in Indirect Tension in dry conditions and after a conditioning of 14 days at $40^{\circ} \mathrm{C}$. Mean Texture Depth (MTD - NF EN 13036-1) were also measured as described in section 2.

\subsection{Results}

The properties measured on the binders are summarized in Fig. 2. First, binder agehardening in the absence of hydrated lime could be observed thru the increase in softening point from an initial value of $54.4^{\circ} \mathrm{C}$ to $68.4^{\circ} \mathrm{C}$ after 5 years (Fig. 2). This hardening was also perceived using other indicators, as illustrated by a similar increase in the temperature at which the complex modulus $\mathrm{G}^{*} / \mathrm{sin}$ delta reaches $1 \mathrm{kPa}$ at $10 \mathrm{rad} / \mathrm{s}$ or a decrease in penetration value (Fig. 2).

On the low temperature side, the temperature at which the BBR modulus $\mathrm{S}(\mathrm{t})$ after 60 s reached $300 \mathrm{MPa}\left(\mathrm{T}_{\mathrm{S}=300}\right)$ or the slope $\mathrm{m}(\mathrm{t})$ reached $0.3 \mathrm{~S}(\mathrm{t})\left(\mathrm{T}_{\mathrm{m}=0.3}\right)$, are seen to increase form an initial value of $-15.3^{\circ} \mathrm{C}$ for both parameters to -12.4 and $-9.4^{\circ} \mathrm{C}$ respectively, showing the well-known observation that the cracking temperature increases with binder aging, hence increasing the risk of observing thermal cracking. 
Note that the initial binder after RTFOT and RTFOT+PAV reached properties that were quite similar to the ones from the binder extracted right after construction and after 5 yrs respectively (Fig. 2).

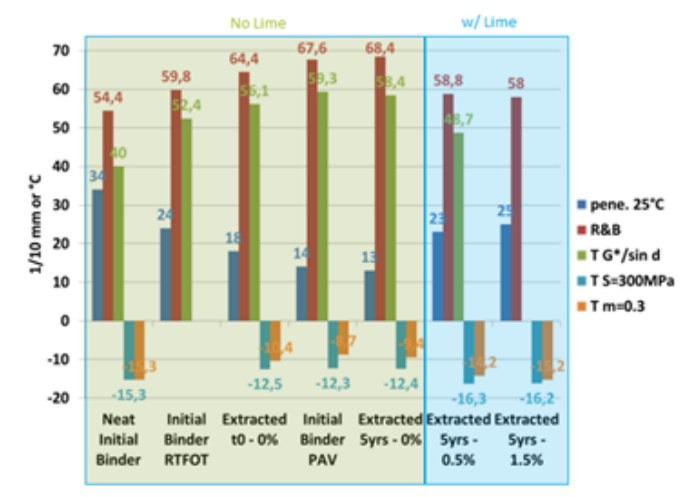

Fig. 2. Rheological properties for the neat initial bitumen, the same binder after laboratory aging (RTFOT and RTFOT+PAV) and the binder extracted from A84 sections after 5 yrs.

In the presence of hydrated lime and after $5 \mathrm{yrs}$, the binder showed a reduced aging with a softening temperature of 58.8 or $58^{\circ} \mathrm{C}$ for respectively 0.5 and $1.5 \%$ hydrated lime. These values were very close to that of the binder right after construction, confirming the reduction in age-hardening imparted by hydrated lime [6]. The other indicators showed the same fact, including for the low temperature fracture-criteria that remained essentially unchanged.

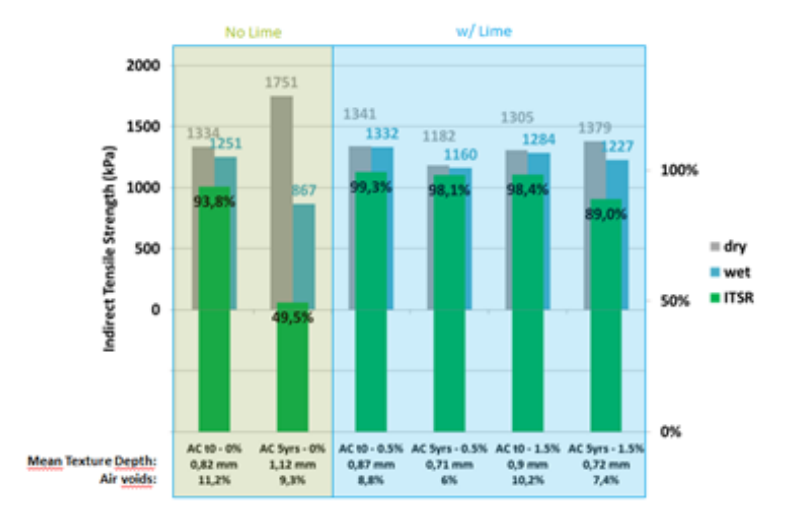

Fig. 3. Indirect Tensile Strength (ITS) for the initial mixtures and after 5 yrs. The ratio (ITSR) between dry and wet ITS is also given. Void content and Mean Texture Depth are also given. 
Note that the chemical indicators, based on both asphaltenes and FTIR, confirmed that the reduced aging in the presence of lime was due to a reduction in the asphaltenes creation. Asphaltenes remained close to $16 \%$ after 5 yrs for the lime sectors when it was 19 after 5 years in the reference one. The slower formation of oxidized compounds such as carbonyls and sulfoxides was also recorded thru FTIR testing.

The results for Indirect Tensile Strength of the mixtures are shown on Erreur ! Source du renvoi introuvable.. After construction, the reference sector showed a pretty high value of $93.8 \%$ for the ITSR, that dropped to $49.5 \%$ after 5 years (Erreur ! Source du renvoi introuvable.). In the presence of lime, the ITSR could be maintained above $85 \%$. Note that air voids for the 5 years-old specimens with lime were also lower (6-7.4\% vs $9.3 \%)$, thus participating to the improved resistance to moisture damage.

\section{Conclusions}

Mixtures with and without hydrated lime were compared in two different French contexts.

First, 20 sections with semi-coarse ACs (BBSG) in the Vosges department were followed for 6 years based on visual observations and measurements of Mean Texture Depth (MTD). This clearly showed that the mixtures with hyrdated lime expereicned less raveling/stripping and pavements with lime after 6 years were in a similar damagestate as the ones without lime after 3 years. The monitoring will be pursued over time in order to see the performance over a longer time frame, trying also to extract cores and test them in a similar way to what was done on highway A84.

Second, the sections on highway A84, also based on BBSG-type mixtures, showed that hydrated lime slowed-down bitumen aging and allowed the mixture to maintain a good resistance to moisture damage even after 5 years. However, no surface damage was yet visible on the test sections regardless of their lime content, even if some very limited raveling/stripping could be observed on the untreated section, as maybe captured by a slightly higher MTD (Erreur ! Source du renvoi introuvable.). Clearly, monitoring must be continued in order to see if the changes recorded in the indicators materialize into premature damage for some of the sections.

\section{References}

1. D. Lesueur, J. Petit and H. J. Ritter (2012), European Roads Review 20, 48-55

2. A. Sainton (2011), Presented to Club d'échanges "Route et Transport" Île de France (in French)

3. D. Lesueur, J. Petit and H.-J. Ritter (2013), Road Mater. Pavement Design 14(1), 1-16

4. O. Chupin, J.-M. Piau, F. Hammoum et al. (2018), Construct. Building Mater. 163, 169-178

5. D. Lesueur, C. Denayer, H. J. Ritter et al. (2016). Proc. 6th E\&E Congress, Prague

6. P. Pibis, J.-B. Siegel, S. El-Bedoui and D. Lesueur (2019), Revue Générale des Routes et Aménagements 961, 69-73 (in French)

7. Pieri, N., Planche, J. P., \& Kister, J. (1996). Analusis, 4(24), 113-122 (in French) 